\title{
DETERMINAN TERHADAP KEPUTUSAN MAHASISWA MEMILIH UNSIKA (Universitas Singaperbangsa Karawang)
}

\author{
DETERMINANT OF STUDENTS IN CHOOSING UNSIKA \\ (University of Singaperbangsa Karawang)
}

\author{
Hani Febrian Agustin \\ Magister Manajemen Fakultas Ekonomi dan Bisnis Unsika \\ Jalan HS.Ronggo Waluyo, Telukjambe Timur, Kab.Karawang, Jawa Barat \\ 41361 \\ *Alumni Magister Manajemen Fakultas Ekonomi dan Bisnis Universitas \\ Singaperbangsa Karawang \\ e-mail: Febrianhani@gmail.com
}

\begin{abstract}
ABSTRAK
Penelitian Determinan Terhadap Keputusan Mahasiswa Memilih Unsika ini telah dilaksanakan pada bulan Juli sampai dengan Oktober 2017. Penelitian ini bertujuan untuk mengetahui seberapa besar faktor bauran pemasaran jasa (marketing mix) 7P berpengaruh terhadap keputusan mahasiswa memilih Unsika dan Untuk mengetahui faktor apa dari bauran pemasaran jasa (marketing mix) 7P. Terdapat 8 (delapan) variabel diantaranya variabel bebas (independent variable) dalam penelitian ini adalah keseluruhan variabel-variabel bauran pemasaran jasa (marketing mix) $7 \mathrm{P}$ yang terdiri dari produk atau program studi $\left(\mathrm{X}_{1}\right)$, harga atau uang $\mathrm{SPP}\left(\mathrm{X}_{2}\right)$, promosi $\left(\mathrm{X}_{3}\right)$, lokasi $\left(\mathrm{X}_{4}\right)$, orang $\left(\mathrm{X}_{5}\right)$, proses $\left(\mathrm{X}_{6}\right)$ pelayanan $\left(\mathrm{X}_{7}\right)$. Variabel terikat (dependent variable) dalam penelitian ini adalah merupakan keputusan mahasiswa untuk memilih Universitas Singaperbangsa Karawang sebagai tempat kuliah untuk mendapatkan pendidikan (Y) yang menunjukan kepuasan mahasiswa memilih Unsika, yaitu keseluruhan upaya atau tindakan mahasiswa yang secara langsung dalam usahanya untuk memilih Universitas Singaperbangsa Karawang sebagai tempat untuk menuntut ilmu. Penelitian ini menggunakan metode studi kasus yang dilakukan di Universitas Singaperbangsa Karawang. Jenis penelitian ini adalah deskriptif kuantitatif dengan model analisis yang digunakan adalah Analisis Regresi Linier Berganda. Jumlah responden sebanyak 360 orang. Pengukuran yang digunakan dalam kuesioner dengan skala Guttman. Hasil penelitian didapatkan koefisien determinanya sebesar 0.664, yang artinya bahwa variabel produk atau program studi $\left(\mathrm{X}_{1}\right)$, harga atau uang $\mathrm{SPP}\left(\mathrm{X}_{2}\right)$, promosi $\left(\mathrm{X}_{3}\right)$, lokasi $\left(\mathrm{X}_{4}\right)$, orang $\left(\mathrm{X}_{5}\right)$, proses $\left(\mathrm{X}_{6}\right)$ pelayanan $\left(\mathrm{X}_{7}\right)$ mampu mempengaruhi keputusan mahasiswa sebesar $66,4 \%$. Berdasarkan hasil uji parsial atau uji t diketahui bahwa variabel orang (X5) berpengaruh paling signifikan terhadap keputusan mahasiswa memilih Unsika, dengan nilai sebesar 23,49\%.Berdasarkan hasil tersebut perlu diperhatikan dan
\end{abstract}

153.

Jurnal Manajemen \& Bisnis Kreatif 
dipertahakankan serta dalam rangka peningkatan pelayanan terhadap faktor tersebut, dapat diupayakan dengan melakukan upgrading atau peningkatan kemampuan terhadap tenaga pengajar atau dosen juga terhadap petugas administrasi kampus.

\section{Kata Kunci : Determinan, Marketing Mix 7P, Keputusan Mahasiswa}

\section{ABSTRACT}

This study has been conducted from July to October 2017. The aim of this study is to identify how much factor marketing mix $7 P$ influenced to the decision of student in choosing University of Singaperbangsa Karawang (UNSIKA) and to examine the factor of marketing mix $7 P$ that is the most significant to students' decision in choosing UNSIKA. There are 8 variables which are independent variable of this study is all the variable of markerting mix $7 p$ that consist of product or study program $\left({ }_{x 1}\right)$, university tuition $\left({ }_{x 2}\right)$, promotion $\left({ }_{x 3}\right)$, placellocation $\left(x_{4}\right)$, people $\left(x_{5}\right)$, process $\left(x_{6}\right)$, servise) $(x 7)$. while, the dependent variable of this study is the decision of students in choosing UNSIKA as the place in getting education (y). It showed the satisfication of students in choosing UNSIKA which are the effort of students in chooisng UNSIKA as the place of studying. The approach of this study is study case which has been conducted in UNSIKA. Therefore, this is descriptive quantitative study whose analysis method is multiple regression analysis. the data of this study were obtained by the answer of 360 students of UNSIKA as respondents through questionnaire. Hence, Guttman scales is used in this study. The result of this study is 0.644 as the determinant coeeficient which means variables such as product or study program $\left(x_{1}\right),\left(x_{1}\right)$, university tuition $(x 2)$, promotion $\left({ }_{x 3}\right)$, placellocation $\left(x_{4}\right)$, people $\left(x_{5}\right)$, process $\left(x_{6}\right)$, influenced the choice of students value of 66.4\%. moreover, the result parsial test or T-test showed that $x 5$ is the has significant influence on students' choice in choosing Unsika value of $23.59 \%$. Hence, the result can be concluded that the service need to be upgraded which can be done by developing of lecturers' ability in lecturing and administration of campus.

\section{keywords: determinant, marketing mix 7p, choice of students}

\section{Pendahuluan}

Bergabungnya Indonesia sebagai bagian dari Masyarakat Ekonomi Asean (MEA) secara resmi pada 31 Desember 2015, memberikan keterbukaan persaingan tidak hanya didalam pertukaran produk namun juga tenaga kerja dengan tidak dibutuhkannya lagi visa tenaga kerja untuk mencari pekerjaan keluar menjadi lebih mudah, sehingga persaingan di lapangan kerja semakin ketat oleh sebab itu tenaga kerja diminta lebih terampil dan ahli dibidangnya sehingga dapat berkualitas, serta dapat mampu bersaing dengan tenaga kerja asing.

Hatten dan Resenthal (2000: 5) menyatakan bahwa penguasaan bidang ilmu dan teknologi dalam kadar yang memadai sangat diperlukan agar masyarakat dapat meningkatkan kemampuan kreativitas, pengembangan, dan penerapan Ilmu 
pengetahuan dan teknologi (IPTEK) sebagai tuntutan yang mutlak dalam kehidupan global. Kaitannya dalam hal ini pendidikan memiliki peranan yang penting.

Kaitannya dengan fenomena tersebut, pendidikan mempunyai peranan yang sangat penting dalam upaya meningkatkan kualitas sumber daya manusia. Untuk meningkatkan efektifitas dan efisiensi penyelenggaraan pendidikan perlu ditingkatkannya kualitas manajemen pendidikan. Berkaitan dengan masalah ini, Engkoswara (2001 : 5) menyebutkan manajemen pendidikan yang diharapkan menghasilkan pendidikan yang produktif, yaitu yang efektif dan efisien memerlukan analisis kebudayaan atau nilai-nilai dan gagasan vital dalam berbagai dimensi kehidupan yang berlaku untuk kurun waktu yang cukup dimana manusia hidup.

Menurut Subandowo (2009: 109-110) pendidikan merupakan salah satu faktor yang sangat fundamental dalam upaya meningkatkan kualitas kehidupan, disamping juga merupakan faktor penentu bagi perkembangan sosial dan ekonomi kearah kondisi yang lebih baik. Pendidikan juga dipandang sebagai saranan paling strategis untuk mengangkat harkat dan martabat suatu bangsa.

Sebagai bentuk kepedulian, negara menjamin dan mengatur pendidikan warganya yang tertuang dalam Undang Undang Dasar 1945 pasal 31. Selain itu, berdasarkan Undang- undang Nomor 20 Tahun 2003 tentang Sistem Pendidikan Nasional memberikan dasar hukum untuk membangun pendidikan nasional dengan menerapkan prinsip demokrasi, desentralisasi, otonomi, keadilan, dan menjunjung tinggi hak asasi manusia. Penerapan ketentuan dalam undangundang ini diharapkan dapat mendukung segala upaya untuk memcahkan masalah pendidikan, guna memberikan sumbangan yang signifikan terhadap masalah- masalah makro bangsa Indonesia.

Berdasarkan hal tersebut, tuntutan kebutuhan pendidikan akan semakin tinggi karena semakin meningkatnya kesadaran masyarakat akan pentingnya pendidikan. Masyarakat semakin paham bahwa pendidikan tidak hanya sebatas sampai sekolah tingkat atas tapi juga pendidikan yang lebih tinggi lagi. Perguruan tinggi menjadi sarana untuk menempuh pendidikan formal tertinggi. Maka, pemilihan perguruan tinggi serta program studi menjadi fokus bagi calon mahasiswa.

Lulusan siswa SMA/SMK sederajat menjadi peluang bagi seluruh perguruan tinggi yang ada di Karawang. Siswa dapat melanjutkan studinya kejenjang pendidikan yang lebih tinggi, baik pada

Tabel 1.1

Jumlah Mahasiswa Perguruan Tinggi di Wilayah Kabupaten Karawang Menurut Tingkat pada Tahun 2015

Tingkat / Grade Jumlah Mahasiswa

\begin{tabular}{cc}
\hline I & \\
(Smst. I \& II) & 4.234 \\
II & \\
$\begin{array}{c}\text { (Smst. III \& IV) } \\
\text { III }\end{array}$ & 4.423 \\
$\begin{array}{c}\text { (Smst. V \& VI) } \\
\text { IV }\end{array}$ & 3.925 \\
$\begin{array}{c}\text { (Smst. VII \& VIII) } \\
\text { V } \\
\text { (Smst. IX \& X) } \\
\text { Jumlah/Total }\end{array}$ & 2.490 \\
\end{tabular}

(Sumber : BPS Publikasi Karawang dalam Angka, 2015)

Perguruan Tinggi Negeri (PTN), maupun

Perguruan Tinggi Swasta (PTS), dalam hal ini baik itu PTN maupun PTS memiliki peluang yang sama untuk dipilih oleh calon mahasiswa. Menurut data BPS (2015), 
jumlah mahasiswa perguruan tinggi di wilayah Kabupaten Karawang menurut tingkat pada tahun ajaran 2013/2014 dapat dilihat pada Tabel 1.1

Jumlah total mahasiswa perguruan tinggi di wilayah Kabupaten Karawang, mayoritas terbanyak adalah mahasiswa Universitas Singaperbangsa Karawang menurut BPS Karawang, 2015.

Universitas Singaperbangsa (Unsika) merupakan universitas negeri yang ada di Kabupaten Karawang. Sejak tanggal 06 Oktober 2014 Unsika (PTS) alih status menjadi Perguruan Tinggi Negeri (PTN) berdasarkan Perpre RI nomor 123 tahun 2014, tentang pendirian Universitas Singaperbangsa Karawang. Terkait dengan hal tersebut, Kementerian Pendidikan dan Kebudayaan (Kemdikbud) menyatakan mendukung transformasi perguruan tinggi swasta (PTS) menjadi perguruan tinggi negeri (PTN), untuk memperluas akses masyarakat khususnya di Kabupaten Karawang dalam mendapat layanan pendidikan.

Selain itu juga dapat memberikan proporsi pencapaian Angka Partisipasi Kasar (APK) Perguruan Tinggi. Angka Partisipasi Kasar (APK) perguruan tinggi pada tahun 2015 berada pada 33,5\% diatas target awal tahun yakni sebesar 26,8\% (Kemenristek, 2015). Berdasarkan data tersebut dapat disimpulkan bahwa transformasi Unsika dari PTS menjadi PTN berdampak pada peningkatan APK perguruan tinggi di Indonesia. Perubahan status Universitas Singaperbangsa menjadi PTN, diharapkan bisa memfasilitasi pelajar yang kurang mampu di wilayah Kabupaten Karawang, dan Jawa Barat dalam mendapatkan layanan pendidikan, dengan begitu Angka Partisipasi Kasar (APK) Kabupaten Karawang juga dapat meningkat.

Peningkatan jumlah peserta yang masuk perguruan tinggi sejalan dengan adanya fluktuasi jumlah mahasiswa Unsika setiap tahun. Jumlah pendaftar ke Unsika dari tahun 2012 sampai dengan 2017 terus mengalami peningkatan. Berdasarkan data tersebut dapat disimpulkan bahwa jumlah peminat Unsika meningkat sejalan dengan meningkatnya kesadaran masyarakat akan pentingnya pendidikan.

Unsika merupakan satu-satunya PTN yang ada di wilayah Karawang. Unsika memiliki sembilan fakultas yaitu, (1) Fakultas Hukum , (2) Fakultas Agama Islam, (3) Fakultas Ekonomi dan Bisnis, (4) Fakultas Ilmu Komputer, (5) Fakultas Ilmu Sosial dan Ilmu Politik, (6) Fakultas Keguruan dan Ilmu Pendidikan, (7) Fakultas Pertanian, (8) Fakultas Teknik dan (9) Fakultas Ilmu Kesehatan. Program studi sebanyak 23 dan dua diantaranya jenjang pascasarjana Ilmu Hukum dan Manajemen (unsika.ac.id, 2017).

Syarat yang dipenuhi suatu universitas agar sukses dalam persaingan adalah berusaha mencapai tujuan dalam mempertahankan jumlah mahasiswa dan lulusan yang dihasilkannya berhasil di dunia kerja. Adanya peningkatan jumlah mahasiswa yang sangat signifikan pada dua tahun terakhir, merupakan fenomena yang sangat menarik untuk diketahui faktor apa yang menyebabkan hal tersebut terjadi.

Jumlah mahasiswa Unsika tahun angkatan 2015 sebanyak 2.797 mahasiswa dan tahun 2016 sebanyak 3.140 mahasiswa. Kaitannya dengan penelitian ini adalah ada fenomena yang sangat menarik sehubungan dengan fluktuasi jumlah mahasiswa Unsika tersebut. Informasi mengenai faktor- faktor apa saja yang mempengaruhi mahasiswa memilih Unsika sebagai tempat memperoleh pendidikan belum banyak 
terungkap. Oleh karena itu penulis tertarik untuk melakukan penelitian tentang faktor apa yang menjadi tolak ukur mahasiswa dalam memutuskan memilih tempat kuliah, degan mengangkat judul "Determinan Terhadap Keputusan Mahasiswa Memilih Unsika".

\section{Metode Penelitian}

Pendekatan dalam penelitian ini menggunakan metode studi kasus yang dilakukan di Universitas Singaperbangsa Karawang dengan mengumpulkan data mengenai faktor-faktor yang terkait dengan variabel penelitian. Menurut Maman Paturochman (2012), metode ini bertujuan untuk memperoleh informasi yang berhubungan dengan sesuatu kejadian (kasus) tertentu saja, studi kasus merupakan metode penelitian yang mempertahankan keutuhan unit analisis yang diteliti.

Jenis penelitian ini adalah deskriptif kuantitatif yaitu untuk mengetahui pengaruh variabel bauran pemasaran yang terdiri dari ; produk, harga, promosi, lokasi, orang, proses, dan pelayanan terhadap keputusan mahasiswa memilih Unsika. Menurut Kuncoro (2003) penelitian deskriptif meliputi pengumpulan data untuk diuji hipotesis atau menjawab pertanyaan mengenai status terakhir dari subjek penelitian. Sifat penelitian ini adalah untuk mengetahui dan menjelaskan pengaruh variabel bauran pemasaran terhadap keputusan mahasiswa memilih Unsika.

\section{Variabel Penelitian}

Variabel bebas (independent variable) dalam penelitian ini adalah keseluruhan variabel-variabel bauran pemasaran jasa yang terdiri dari produk atau program studi $\left(\mathrm{X}_{1}\right)$, harga atau uang SPP $\left(\mathrm{X}_{2}\right)$, promosi $\left(\mathrm{X}_{3}\right)$, lokasi $\left(\mathrm{X}_{4}\right)$, orang $\left(\mathrm{X}_{5}\right)$, proses $\left(\mathrm{X}_{6}\right)$ pelayanan $\left(\mathrm{X}_{7}\right)$.

Variabel terikat (dependent variable) dalam penelitian ini adalah merupakan keputusan mahasiswa untuk memilih Universitas Singaperbangsa Karawang sebagai tempat kuliah untuk mendapatkan pendidikan (Y) yang menunjukan kepuasan mahasiswa memilih Unsika, yaitu keseluruhan upaya atau tindakan mahasiswa yang secara langsung dalam usahanya untuk memilih Universitas Singaperbangsa Karawang sebagai tempat untuk menuntut ilmu.

\section{Populasi Penelitian}

Sugyono (2004: 72) mengatakan populasi adalah wilayah generalisasi yang terdiri dari subjek atau objek yang mempunyai kualitas dan karakteristik tertentu yang ditetapkan oleh peneliti untuk dipelajari kemudian ditarik kesimpulannya.

Populasi dalam penelitian ini adalah mahasiswa (1) Fakultas Hukum , (2) Fakultas Agama Islam, (3) Fakultas Ekonomi dan Bisnis, (4) Fakultas Ilmu Komputer, (5) Fakultas Ilmu Sosial dan Ilmu Politik, (6) Fakultas Keguruan dan Ilmu Pendidikan, (7) Fakultas Pertanian, (8) Fakultas Teknik dan (9) Fakultas Ilmu Kesehatan di Unsika angkatan tahun 2016.

\section{Sampel}

Arikunto (2002: 109) mengatakan sampel adalah sebagian atau wakil dari populasi yang diteliti. Teknik pengambilan sampel yang digunakan dalam penelitian ini adalah proportionate stratified random sampling. 
Sugiyono (2012: 93) mengatakan proportionate stratified random sampling adalah teknik sampling yang digunakan bila populasi mempunyai anggota atau unsur yang tidak homogen dan berstrata secara proporsional. Untuk menentukan siapa yang akan dijadikan responden dari masing-masing strata dilakukan secara acak atau random. Dalam menentukan besarnya sample pada penelitian ini digunakan teknik slovin (Sevilla et. al., 1960: 182), sebagai berikut:

$$
n=\frac{N}{1+N e^{2}}
$$

Keterangan : $\mathrm{n}=$ sample

$\mathrm{N}=$ populasi

$\mathrm{e}=$ batas tolenrasi

kesalahan (error tolerance)

Berdasarkan jenis data, pada penelitian ini data yang digunakan adalah kuantitatif. Data kuantitatif adalah data yang dipaparkan dalam bentuk angka-angka. Penelitian ini termasuk penelitian data kuantitatif, dimana data kuantitatif yang berasal dari skor data jawaban responden dari tiap pertanyaan yang dianalisis dengan mengutamakan analisis statistik. Macam data yang dikuantitatifkan dalam penelitian ini merupakan data dengan skala nominal. Instrumen yang digunakan dalam penelitian ini akan diukur dengan menggunakan ukuran nominal. Ukuran nominal tidak mengasumsikan tentang jarak ataupun urutan antara kategori-kategori dalam ukuran tersebut. Dasar penggolongannya hanyalah kategori yang tidak tumpang tindih dan tuntas (Singarimbun Masri dan Effendi, 2011). Pengukuran nominal diwakili dalam penggunaan skala Guttman.

Teknik pengumpulan data dengan wawancara (interview) dilakukan langsung kepada pihak yang berhak atau berwenang memberikan imformasi, daftar pertanyaan dan atau pernyataan (questionaire) diberikan langsung kepada mahasiswa, studi dokumentasi dengan mengumpulkan dan mempelajari data atau dokumen yang mendukung.

Pengujian validitas dan reliabilitas instrumen selanjutnya akan dihitung dengan menggunakan program SPSS (Statistical Packed for Social Science). Untuk memperoleh tingkat validitas instrumen kuesioner dalam skala Guttman dilakukan dengan menggunakan koefisiensi reprodusibilitas (Kr) dan koefisiensi skalabilitas (Ks). Untuk penghitungan secara praktis koefisien reprodusibilitas dan koefisien skalabilitas peneliti menggunakan program komputer SKALO, analisis skala Guttman Versi 02Excel. Adapun penghitungan secara manual dapat dilakukan dengan cara dibawah. Skala yang memiliki nilai $\mathrm{Kr}>0,90$ dianggap baik. Sementara dalam perhitungan koefisien skalabilitas jika nilai $\mathrm{Ks}>0,60$ dianggap baik untuk digunakan dalam penelitian (Singarimbun, Masri dan Effendi, 2011).

Teknik pengujian realibilitas menggunakan alpha cronbach dengan taraf nyata 5\% (0,05). Untuk menilai reliabel tidaknya instrumen dapat dilakukan dengan mengkonsultasikan hasil perhitungan alpha cronbach dengan angka tabel $\mathrm{r}$ product moment. Jika diperoleh $\mathrm{r}$ hitung (koefisien alpha cronbach) lebih besar daripada $\mathrm{r}$ tabel maka instrumen tersebut reliabel. Sebaliknya jika $\mathrm{r}$ hitung (koefisien alpha 
cronbach) lebih kecil daripada $\mathrm{r}$ tabel berarti instrumen tersebut tidak reliabel (Arikunto, 2013:238).

Untuk mengetahui apakah data tersebut mengikuti sebaran normal dapat dilakukan dengan berbagai metode, diantaranya metode Komogorov-Smirnov. Sebuah data bisa dikatakan normal atau tidak, jika p-value > 0,05 (Sudjana, 2002:273).

Permasalahan dalam Regresi Linear Berganda selain dilakukan uji diatas juga perlu diadakan pengujian yang berkaitan Multikolinearitas dan heterokedastisitas. Ini timbul pada saat asumsi bahwa varian dari faktor alat adalah konstan untuk semua variabel bebas yang tidak terpenuhi. Jika varian tidak sama, dikatakan terjadi heterokedastisitas. Untuk mendeteksi ada tidaknya heterokedastisitas dalam model regresi digunakan Analisis Residual yang berupa grafik dengan dasar pengambilan keputusan jika pola tertentu seperti titik- titik yang ada membentuk suatu pola tertentu yang teratur, maka terjadilah heterokedastisitas. Jika tidak ada pola yang jelas, serta titik- titik menyebar dibawah angka 0 pada sumbu $Y$ tidak terjadi heterokedastisitas.

\section{Analisis Regresi Linier Berganda}

Untuk mengetahui pengaruh produk, harga, promosi, tempat, orang, proses, dan pelayanan terhadap keputusan Mahasiswa memilih Universitas Singaperbangsa Karawang, maka digunakan Analisis Regresi Berganda dengan persamaan berikut:

$$
Y=a+\beta_{1} X_{1}+\beta_{1} X_{1}+\beta_{1} X_{1}+\beta_{1} X_{1}+\beta_{1} X_{1}+\beta_{1} X_{1}+\beta_{1} X_{1}+e
$$

dimana :

$\mathrm{Y} \quad=$ Keputusan mahasiswa

a $\quad=$ Konstanta

$\beta 1=$ Koefisien variabel X1

$\beta 2=$ Koefisien variabel X2

$\beta 3=$ Koefisien variabel $\mathrm{X} 3$

$\beta 4 \quad=$ Koefisien variabel X4

$\beta 5 \quad=$ Koefisien variabel $\mathrm{X} 5$

$\beta 6=$ Koefisien variabel $\mathrm{X} 6$

$\beta 7 \quad=$ Koefisien variabel $\mathrm{X} 7$

$\mathrm{X} 1=$ Produk (program studi)

X2 = Harga (uang SPP)

$\mathrm{X} 3=$ Promosi

$\mathrm{X} 4=$ Lokasi

$\mathrm{X} 5=$ Orang

$\mathrm{X} 6=$ Proses

$\mathrm{X} 7 \quad=$ Pelayanan

e $\quad=$ Standar eror

Untuk menguji signifikansi faktor-faktor tersebut secara bersama-sama terhadap keputusan mahasiswa memilih Universitas Singaperbangsa Karawang, digunakan rumus uji F (Sugiyono, 2002), yaitu: 
$F=\frac{R^{2} / K}{1-R^{2}(n-k-1)}$

Keterangan :

$\mathrm{R}^{2} \quad=$ Koefisien korelasi ganda

$\mathrm{k} \quad=$ Jumlah variabel independen

$\mathrm{n} \quad=$ Jumlah anggota sampel

Pada uji F, dengan tingkat kepercayaan (confidence interval) 95\% atau $\alpha=0,05$ apabila hasil perhitungan nilai signifikan F lebih kecil dari $\alpha=0,05$ maka Ho ditolak dan $\mathrm{Ha}$ diterima, hal ini berarti bahwa varibel-variabel independen-nya secara bersama-sama mempunyai pengaruh yang signifikan terhadap variable dependennya.

Untuk menguji signifikansi faktor-faktor tersebut secara parsial terhadap keputusan mahasiswa memilih Business College LP3I Medan, digunakan rumus uji t, (Sugiyono, 2002) yaitu :

Keterangan:

$$
t=\frac{r+\sqrt{n-2}}{\sqrt{1-r^{2}}}
$$

$\mathrm{r} \quad=$ Koefisien korelasi

$\mathrm{n} \quad=$ Jumlah responden $(\mathrm{n}-2=\mathrm{dk}$, derajat kebebasan)

Apabila hasil uji t dengan tingkat kepercayaan ( Confident Interval) sebesar $95 \%$ atau $\alpha=0,05$ nilai signifikan t lebih kecil dari $\alpha=0,05$ maka Ho ditolak.

\section{Hasil dan Pembahasan}

Responden dalam penelitian ini adalah mahasiswa Unsika angkatan 2016, dengan karakteristik sebagai berikut :

1. Jumlah Responden Berdasarkan Jenis Kelamin

Tabel 3.1

Jumlah Responden Berdasarkan Jenis Kelamin

\begin{tabular}{llcc} 
No & Jenis Kelamin & Jumlah (orang) & Persentase (\%) \\
\hline 1. & Laki- laki & 175 & \\
2. & Perempuan & 185 & 48,6 \\
\hline & Total & 360 & 51,4 \\
\hline
\end{tabular}

Sumber : Hasil Pengolahan Data oleh Peneliti, 2017

1. Jumlah Responden Berdasarkan Usia

Tabel 3.2

Jumlah Responden Berdasarkan Usia

160.

Jurnal Manajemen \& Bisnis Kreatif 


\begin{tabular}{lccc} 
No & Rentang Usia & Jumlah (orang) & Persentase (\%) \\
\hline 1. & $<20-20$ tahun & 195 & 54,2 \\
2. & $>20$ tahun & 165 & 45,8 \\
\hline & Total & 360 & 100 \\
\hline
\end{tabular}

Sumber : Hasil Pengolahan Data oleh Peneliti, 2017

2. Jumlah Responden Berdasarkan Asal

Tabel 4.3

Jumlah Responden Berdasarkan Asal

\begin{tabular}{llcc}
\hline No & \multicolumn{1}{c}{ Asal } & Jumlah (orang) & Persentase (\%) \\
\hline 1 & Karawang & 117 & 32.5 \\
2 & Bandung & 65 & 18.1 \\
3 & Bekasi & 38 & 10.6 \\
4 & Purwakarta & 30 & 8.3 \\
5 & Jakarta & 26 & 7.2 \\
6 & Tanggerang & 23 & 6.4 \\
7 & Subang & 18 & 5.0 \\
8 & Bogor & 15 & 4.2 \\
9 & Garut & 11 & 3.1 \\
10 & Cirebon & 6 & 1.7 \\
11 & Jambi & 4 & 1.1 \\
12 & Jogjakarta & 2 & 0.6 \\
13 & Surabaya & 2 & 0.6 \\
14 & Sragen & 2 & 0.6 \\
15 & Medan & 1 & 0.3 \\
\hline \multicolumn{2}{c}{ Total } & 360 & $100 \%$ \\
\hline
\end{tabular}

Sumber : Hasil Pengolahan Data oleh Peneliti, 2017

Dalam penelitian ini pengujian uji validitas menggunakan program analisis skala Guttman Versi 02-Excel. Uji validitas dilakukan pervariabel dengan sampel percobaan berjumlah 50 orang. Syarat penerimaan nilai koefisien reprodusibiltas yaitu apabila koefisien reprodusibiltas memiliki nilai $>0,90$. Syarat penerimaan nilai koefisien skalabilitas yaitu apabila koefisien skalabilitas memiliki nilai >0, 60 . Berdasarkan program diperoleh variabel penelitian sudah memiliki koefisien reprodusibiltas $>0,90$ dan koefisien skalabilitas $>0,60$ sehingga item pada variabel valid atau layak digunakan untuk mengukur masing-masing variabel.

Hasil uji normalitas nilai residual menunjukkan nilai Zhitung diatas Ztabel (Ztabel=1,96) dan signifikansi diatas 0,05. Nilai Zhitung yaitu 1,042 dan signifikansi 0,227 . Oleh karena itu dapat dikatakan bahwa data dalam penelitian ini sudah berdistribusi normal.

Uji multikolinearitas dapat dilihat dari nilai VIP (Variance Inflation Factor) dan toleransi. Nilai Tolerance sudah diatas 0,1 dan VIF dibawah 10 sehingga tidak 
ada multikolinieritas. Hasil uji heteroskedastisitas yang diperoleh nilai signifikansi pada semua variabel sudah diatas 0,05 sehingga tidak terdapat heteroskedastisitas.

Hipotesis kemudian di Uji menggunakan Analisis Regresi Linier Berganda. Berikut hasil analisis deskriptifnya:

Descriptive Statistics

\begin{tabular}{|l|c|r|r|r|r|}
\hline & N & Min & Max & Mean & $\begin{array}{c}\text { Std. } \\
\text { Deviatio } \\
\mathrm{n}\end{array}$ \\
\hline X1 & 360 & .00 & 1.00 & .8556 & .22307 \\
X2 & 360 & .00 & 1.00 & .6854 & .31967 \\
X3 & 360 & .00 & 1.00 & .6362 & .38113 \\
X4 & 360 & .00 & 1.00 & .7139 & .37144 \\
X5 & 360 & .00 & 1.00 & .7278 & .29182 \\
X6 & 360 & .00 & 1.00 & .7674 & .29776 \\
X7 & 360 & .00 & 1.00 & .6789 & .31134 \\
Y1 & 360 & .00 & 1.00 & .8528 & .35482 \\
Valid N & 360 & & & & \\
(listwise) & & & & & \\
\hline
\end{tabular}

Y1

\begin{tabular}{|c|c|c|c|c|c|}
\hline & & $\begin{array}{l}\text { Frequ } \\
\text { ency }\end{array}$ & Percent & $\begin{array}{c}\text { Valid } \\
\text { Percent }\end{array}$ & $\begin{array}{l}\text { Cumulativ } \\
\text { e Percent }\end{array}$ \\
\hline \multirow{3}{*}{$\begin{array}{l}\text { Val } \\
\text { id }\end{array}$} & $\begin{array}{l}\text { Tida } \\
\mathrm{k} \\
\text { Puas }\end{array}$ & 53 & 14.7 & 14.7 & 14.7 \\
\hline & Puas & 307 & 85.3 & 85.3 & 100.0 \\
\hline & Total & 360 & 100.0 & 100.0 & \\
\hline
\end{tabular}

Sumber : Pengolahan Data oleh Penulis, 2017

Untuk mengetahui pengaruh hipotesis X1 Produk (program studi), X2 harga (uang SPP), X3 Promosi, X4 Lokasi, X5 Orang, X6 Proses, dan X7 Pelayanan terhadap keputusan Mahasiswa memilih Universitas Singaperbangsa Karawang, maka digunakan Analisis Regresi Berganda dengan persamaan berikut:

$\mathrm{Y}=-\mathbf{0 , 1 5 1 + 0 , 3 1 7 X 1 + 0 , 1 0 1 \times 2 + 0 , 2 2 0 \times 3 +}$

$0,015 \times 4+0,419 \times 5+0,110 \times 6+0,181 \times 7$

Dimana :

Y = Keputusan mahasiswa

$0,151=$ Konstanta

$0,317=$ Koefisien variabel $\mathrm{X} 1$

$0,101=$ Koefisien variabel $\mathrm{X} 2$

$0,220=$ Koefisien variabel X3 
$0,015=$ Koefisien variabel $\mathrm{X} 4$

$0,019=$ Koefisien variabel $\mathrm{X} 5$

$0,110=$ Koefisien variabel X6

$0,181=$ Koefisien variabel $\mathrm{X} 7$

$\mathrm{X} 1=$ Produk (program studi)

$\mathrm{X} 2=$ Harga (uang SPP)

$\mathrm{X} 3=$ Promosi

$\mathrm{X} 4=$ Lokasi

$\mathrm{X} 5=$ Orang

$\mathrm{X} 6=$ Proses

X7 = Pelayanan

Hasil koefisien determinasi diatas yaitu 0,664 yang dapat dikatakan variabel $\mathrm{X} 1, \mathrm{X} 2, \mathrm{X} 3, \mathrm{X} 4, \mathrm{X} 5, \mathrm{X} 6$, dan X7 mampu mempengaruhi keputusan mahasiswa sebesar $66,4 \%$ sedangkan sisanya yaitu $33,6 \%$ dipegaruhi oleh variabel lain yang tidak menjadi fokus dalam penelitian ini.

\begin{tabular}{|c|c|c|c|c|c|}
\hline \multicolumn{6}{|c|}{ ANOVA $^{\mathrm{a}}$} \\
\hline Model & $\begin{array}{c}\text { Sum of } \\
\text { Squares }\end{array}$ & df & $\begin{array}{l}\text { Mean } \\
\text { Square }\end{array}$ & $\mathrm{F}$ & Sig. \\
\hline Regression & 29.993 & 7 & 4.285 & 99.198 & $.000^{b}$ \\
\hline $1 \quad$ Residual & 15.204 & 352 & .043 & & \\
\hline Total & 45.197 & 359 & & & \\
\hline
\end{tabular}

a. Dependent Variable: Y1

b. Predictors: (Constant), X7, X1, X2, X4, X6, X3, X5

Berdasarkan Tabel Anova adanya pengaruh secara bersama-sama antar variabel independen jika nilai $\mathrm{F}$ hitung lebih besar dari $\mathrm{F}$ table dan signifikansi lebih kecil dari 0,05. Nilai $F$ hitung yaitu 99,198 dan signifikansi 0,000 sehingga nilai $F$ hitung lebih besar dari $\mathrm{F}$ table dan signifikansi lebih kecil dari 0,05, dapat diambil kesimpulan bahwa terdapat pengaruh simultan dari variabel X1,X2,X3,X4,X5,X6, dan X7 terhadap kepuasan (Y).

Adanya pengaruh yang signifikan jika nilai t hitung lebih besar dari t tabel dan nilai signifikansi lebih kecil dari 0,05 (standar error).

Berikut hasil uji parsial (Uji t): 


\begin{tabular}{|c|r|r|r|r|}
\hline \multirow{2}{*}{ Model } & St. Coefficients & \multicolumn{3}{|c|}{ Correlations } \\
\cline { 2 - 5 } & Beta & Zero-order & Partial & Part \\
& & & & \\
\hline & & & & \\
X1 & .199 & .496 & .279 & .169 \\
X2 & .091 & .481 & .130 & .076 \\
X3 & .237 & .558 & .294 & .178 \\
X4 & .016 & .440 & .022 & .013 \\
X5 & .345 & .681 & .398 & .251 \\
X6 & .092 & .545 & .122 & .071 \\
X7 & .159 & .610 & .198 & .117 \\
\hline
\end{tabular}

Untuk mengetahui besar pengaruh masing-masing variabel terhadap (Y) yaitu dengan mengalikan Beta dengan Zero Order (korelasi parsial X terhadap Y). Berikut hasilnya :

\section{Simpulan dan Saran}

\section{Simpulan}

1. Faktor bauran pemasaran jasa (marketing mix) 7P yaitu produk (program studi) $\left(\mathrm{X}_{1}\right)$, harga (uang SPP) $\left(\mathrm{X}_{2}\right)$, promosi $\left(\mathrm{X}_{3}\right)$, lokasi $\left(\mathrm{X}_{4}\right)$, orang $\left(\mathrm{X}_{5}\right)$, proses $\left(\mathrm{X}_{6}\right)$ pelayanan $\left(\mathrm{X}_{7}\right)$ mempengaruhi keputusan mahasiwa memilih Unsika sebesar $66,4 \%$.

2. Faktor dari (marketing mix) 7P yang paling signifikan mempengaruhi keputusan mahasiwa memilih Unsika adalah faktor Orang $\left(\mathrm{X}_{5}\right)$ sebesar 23,49 $\%$. Faktor Produk (program studi) $\left(\mathrm{X}_{1}\right)$ berpengaruh sebesar 9,87\%, Faktor Harga (uang SPP) $\left(\mathrm{X}_{2}\right)$ berpengaruh sebesar 4,38\%, Faktor Promosi $\left(\mathrm{X}_{3}\right)$ berpengaruh sebesar $13,22 \%$, Faktor lokasi $\left(\mathrm{X}_{4}\right)$ tidak terdapat pengaruh secara parsial, faktor proses $\left(\mathrm{X}_{6}\right)$ berpengaruh sebesar 5,01\%, faktor pelayanan

\begin{tabular}{|c|c|}
\hline Variabel & Besar Pengaruh $\mathbf{X} \rightarrow \mathbf{Y}$ \\
\hline $\mathrm{X} 1$ & $9.87 \%$ \\
\hline $\mathrm{X} 2$ & $4.38 \%$ \\
\hline $\mathrm{X} 3$ & $13.22 \%$ \\
\hline $\mathrm{X} 4$ & $0.70 \%$ \\
\hline $\mathrm{X} 5$ & $23.49 \%$ \\
\hline $\mathrm{X} 6$ & $5.01 \%$ \\
\hline $\mathrm{X} 7$ & $9.70 \%$ \\
\hline
\end{tabular}

$\left(\mathrm{X}_{7}\right)$ 


\section{Saran}

berpengaruh sebesar $9,70 \%$.

1. Berdasarkan hasil penelitian faktor Orang $\left(\mathrm{X}_{5}\right)$ yaitu berupa kompetensi dosen, pelayanan petugas administrasi, berpengaruh paling signifikan terhadap Keputusan Mahasiswa Memilih Unsika. Sehingga perlu diperhatikkan dan dilakukan peningkatan pelayanan terhadap faktor tersebut, dapat diupayakan dengan melakukan upgrading atau peningkatan kemampuan terhadap tenaga pengajar atau dosen juga terhadap petugas administrasi kampus. Dapat juga dirumuskan untuk dibuatkan standar operasional pelayanan kampus.

2. Secara simultan faktor (marketing mix) $7 \mathrm{P}$ berpengaruh sebesar $66,4 \%$, oleh karena itu disarankan agar dapat mempertahankan strategi marketing jasa pendidikan ini dan dapat diupayakan untuk lebih meningkatkan strategi marketing jasa, dengan cara melakukan evaluasi secara berkala.

\section{DAFTAR PUSTAKA}

Akreditasi.net. 2017. Akreditasi Perguruan Tinggi di Karawang. (diakses pada tangga 11 Desember 2017)

Arikunto, Suharsimi. 2002. Metodologi Penelitian. PT. Rineka Cipta. Jakarta.

Arikunto, S. 2013. Prosedur Penelitian: Suatu Pendekatan Praktik. Rineka Cipta. Jakarta.

Badan Pusat Statistik Kabupaten Karawang. 2015. Karawang dalam Angka Tahun 2015. karawangkab.bps.go.id (diakses pada Rabu, 12 April 2017 Pukul 15.30)

Engkoswara. 2001. Paradigma Manajemen Pendidikan: Menyongsong Otonomi Daerah. Edisi ke-2. Yayasan Amal Keluarga. Bandung.

Hatten, Kenneth. J. dan Stephen, R. Rosenthal. 2000. Reaching for the Knowledge Edge. Amacom. New York. Hermawan Kartajaya. 2002.

Kuncoro, Mudrajad. 2003. Metode Riset untuk Bisnis dan Ekonomi. Erlangga. Jakarta. Sevilla, C. G.et. al. 1960. Research Methods. Rex Printing Company. Quezon City.

Singarimba, Masri, Sofian Effendi. 2011. Metode Penelitian Survai. LP3ES. Jakarta. JakartaStanton, William. 1996. Prinsip-prinsip Pemasaran, Jilid Kedua, Edisi Ketujuh. Erlangga. Jakarta.

Subandowo. 2009. Peningkatan Produktivitas Guru dan Lembaga Pendidikan Tenaga Kependidikan Pada Era Global. Jurnal Ilmiah Kependidikan, Khazanah Pendidika, Vol. I, No. 2.

Sudjana. 2002. Metode Statistika. Tarsito. Bandung.

Sugiyono. 2012. Memahami Penelitian Kualitatif. Alfabeta. Bandung.

Sugiyono. 2004. Metode Penelitian Bisnis. Alfabeta. Bandung.

Undang Undang Dasar 1945 pasal 31.

Undang Undang Nomor 20 Tahun 2003.

Unsika. 2017. Akreditasi. Karawang. (via Unsika.ac.id diakses pada tanggal 25 November 2017)

Paturochman, Maman. 2012. Penentuan Jumlah dan Teknik Pengambilan Sampel (Untuk Penelitian Sosial Ekonomi). Unpad Press. Bandung. 